\title{
The mechanical life of implements operating in corrosive service
}

\author{
Galia Kokieva ${ }^{1, *}$, Marfa Ochlopkova $^{2}$, Yurii Shaposhnikov ${ }^{3}$, and Varvara Trofimova ${ }^{1}$ \\ ${ }^{1}$ Arctic State Agrotechnological University, 3, Sergelyakhskoe highway, 3 km, 677007, Yakutsk, the \\ Republic of Sakha (Yakutia), Russia \\ ${ }^{2}$ North-Eastern Federal University named after M.K. Ammosov, 58, Belinskogo st., 677007, Yakutsk, \\ the Republic of Sakha (Yakutia), Russia \\ ${ }^{3}$ Altai State Technical University named after I. I. Polzunov. 46, Lenin Avenue, 656038, Barnaul, \\ Altai Krai, Russia
}

\begin{abstract}
In severe operating conditions, there are machines for the preparation and introduction of mineral and organic fertilizers, herbicides, pesticides. They fail in order after two or three years due to corrosion and corrosion-mechanical wear. Under these conditions, the main thing is not to protect individual details, but the protection of the machine as a whole. Disclosure of the mechanism and patterns of corrosion-mechanical wear and corrosion of structural materials in aggressive environments made it possible to scientifically substantiate the most effective ways to increase the service life of machines at the stages of design, manufacturing and operation. Passive working bodies (frame, body, tank) polymer and gummed coatings are reliably protected from corrosion. Corrosion damage to the details of agricultural machines during storage. The illustrated surfaces of the working bodies of plows, seeders, cultivators, disk harrows and other agricultural machines in the storage period are oxidized and coated with rust. In some cases, it appears due to the destruction of the protective film of paint in others - due to violation of the storage rules. The lower parts of agricultural machines made of simple carbonistic structural and unfounded steels, in contrast to parts remote from the soil and no contact with it, corroded intensively.
\end{abstract}

\section{Introduction}

Corrosion damages component parts ofthe implements during storage. Unpreserved surfaces of the working tools of plows, sowing drills, cultivators, disc harrows and other implements are oxidized and incrust. Contamination on component parts increases corrosion, because in combination with damp, they can create an active electrochemical environment that causes intense corrosion processes.First of all, corrosion damages the exposed surfaces. In some cases, it caused by the paint degradation (during transportation, work, etc.), in others by incorrect storage. The lower parts of the implements (shares, lower track wheels, transport wheel, etc.) made of simple carbon structural and low-alloy steels, compared to component parts that do not contact with soil, corrode more intensively $[1,8,14]$. The depth of damage of some component parts reaches intolerably large sizes.So, if axles, seed boxes, protective covers, frames are damaged to a depth of

\footnotetext{
${ }^{*}$ Corresponding author: kokievagalia@mail.ru
} 
$0.02 \ldots 0.07 \mathrm{~mm}$ in a year, then parts of working tools and supporting parts, contacting with the soil $-0.42 \ldots 0.44 \mathrm{~mm}$.

Corrosion is most dangerous for assembly component parts operating under cyclic or impact loads (springs, spring hoes, axles, shafts, etc.). The mechanical life of parts is very often reduced by $40 \ldots \ldots 80 \%$ because of fatigue fractures in practice.In examining fractures, parts (cultivator shares, shafts, etc.), it has been found that pitting corrosion setthe beginning of many fractures.

Deterioration is a change of the physicochemical propertiesof materials during theirserviceas time passes. This is because of the destruction processes, that is, the molecular decomposition of the backbone chain.

\section{Results and discussion}

The most common method of anticorrosion protection of theimplements' outside surfaces in preparing them for storage is a preservationof them with various protective materials. For these purposes, viscous lubrication, conservation oils and greases, protective wax dispersions, film-forming inhibited petroleum compositions, gasoline-bituminous compositions, oil-soluble and anticorrosive additives are used.The main criteria for the selection of preservation materials are the corrosiveness of the environment, the way of storage, the condition of the protected surface, the duration of protection, the application processand the need for depreservation[2,9,15].

Materials based on liquid rubber are advanced for protecting implements from corrosion and mechanochemical wear. The wear and corrosion resistance in mineral fertilizers of rubberized coats based on polychloroprene NT and their compositions with various fillers have been studied $[3,5,13]$.

Rubbers have a special place among polymeric materials due to their high elasticity. Rubber coatings resist abrasion. The research results show that the volumetric wear of the rubberized coats in comparison with steel $\mathrm{St} 3$ in free running mineral fertilizers is less by almost $25 \%$.

Table 1. The corrosion area of the mineral fertilizer spreader's component parts 1RMG-4 (after two years of service).

\begin{tabular}{|l|c|c|}
\hline Component parts & Corrosionarea, dm2 & Sub-division of total area,\% \\
\hline Frame rails & 399 & 95 \\
\hline Sides: & $280 / 285$ & $88 / 82$ \\
sideboard & $83 / 67$ & $72 / 61$ \\
body front & $94 / 110$ & $80 / 100$ \\
tailgate & $0 / 150$ & $0 / 100$ \\
\hline Bodybottomplate & $31 / 31$ & $100 / 100$ \\
\hline Dispencingthrottle & 69 & 87 \\
\hline \multicolumn{2}{|l|}{ Spreader disk } & in \\
\hline \multicolumn{2}{|l|}{ Note. In the numerator - data for the inside, in the denominator - for the outside surfaces } \\
\hline
\end{tabular}





It is necessary to use additives of various ingredients (flexibilizers, antideteriorants, fillers, etc.)to improve the protective properties of polymeric coatings. As Table 2 shows, coatings made of polyethylenewith poly- $n$-hydroxybenzophenonedisulphide, dicumyl and benzoyl additiveshave the best protective properties. 
Table2. Protective ability of polymer coatings.

\begin{tabular}{|l|c|c|}
\hline \multirow{2}{*}{ Coating } & \multicolumn{2}{c|}{ Corrosionappearancetime, months } \\
\cline { 2 - 3 } & ammoniumsaltpeter & pigmanureslurry \\
\hline Polyethylene & 8 & 10 \\
\hline $20 \%$ epoxy oligomer E-41polyethylene & 16 & 18 \\
\hline $10 \%$ polyisobutylene polyethylene & 14 & 16 \\
\hline $15 \%$ vinylamidepolyethylene & 18 & 18 \\
\hline $0.5 \%$ poly-n-hydroxybenzophenonedisulphide polyethylene & 36 & 40 \\
\hline $1 \%$ benzoylperoxidepolyethylene & 18 & 24 \\
\hline Полиэтилен c 0,5\% перекиси дикумилата & 24 & 24 \\
$0.5 \%$ dicumylateperoxidepolyethylene & & \\
\hline $10 \%$ titanium dioxide polyethylene & 16 & 20 \\
\hline $10 \%$ siliconedioxidepolyethylene & 14 & 18 \\
\hline Polyvinylbutyral & 7 & 10 \\
\hline $10 \%$ polyethylene polyvinylbutyral & 16 & 20 \\
\hline $10 \%$ nylons polyvinylbutyral & 24 & 24 \\
\hline $30 \%$ polyvinylchloridepolyvinylbutyral & 14 & 16 \\
\hline Fluoroplastic & 8 & 8 \\
\hline $20 \%$ epoxy oligomer E-41 fluoroplastic & 16 & 18 \\
\hline Polyvinylchloride & 7 & 9 \\
\hline $20 \%$ epoxy oligomer E-41 polyvinylchloride & 12 & 14 \\
\hline
\end{tabular}

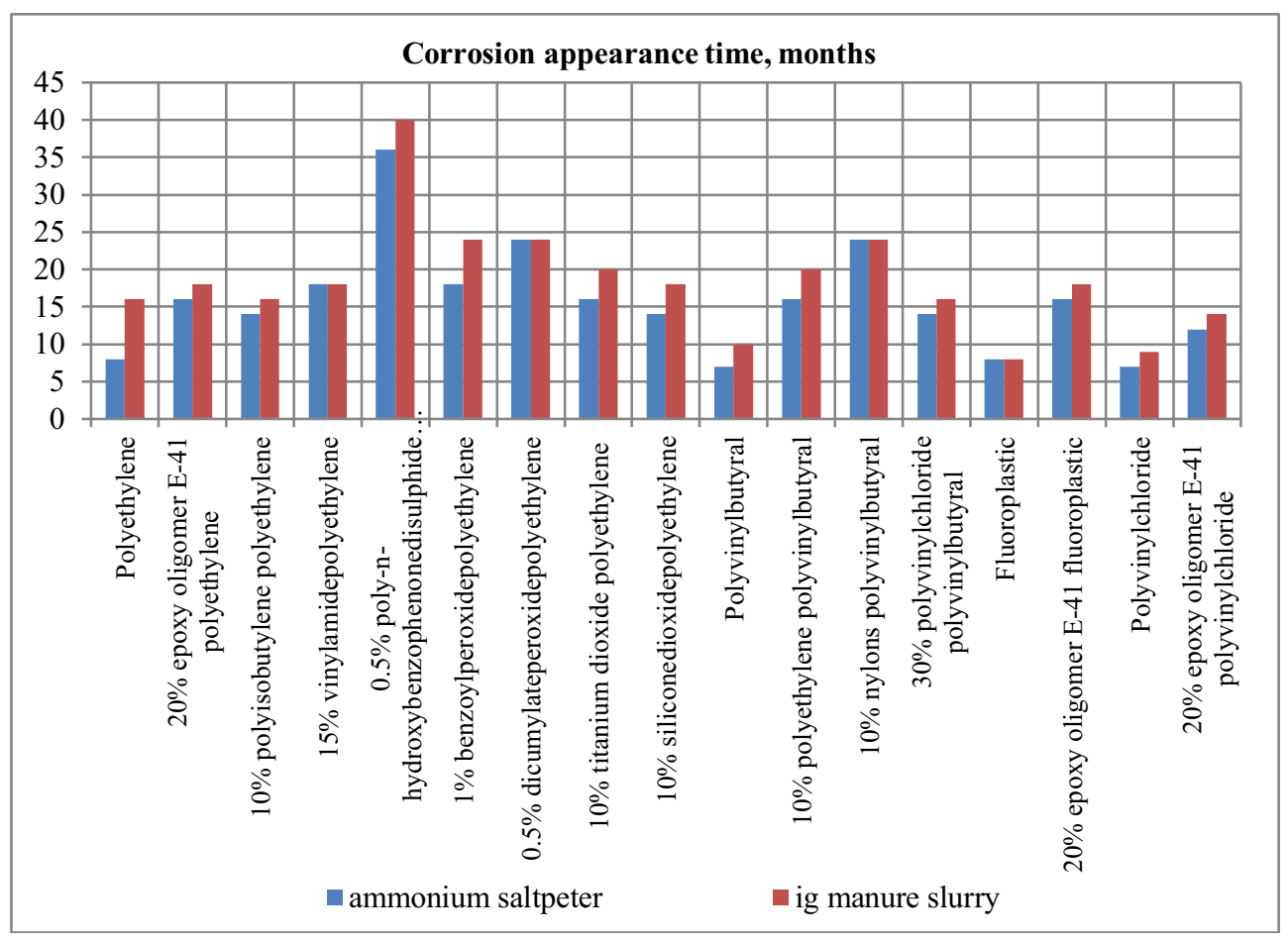

The wear resistance of hardened steels has been studied during friction in the mass of mineral fertilizers using an impellerinstallation. The impact of the corrosion factor has been obtained by comparing the wear rate in two regimes of friction - continuous and intermittent, at intervals: $30 \mathrm{~min}$ - stop, $1 \mathrm{~min}$ - friction. The fertilizer corrosiveness

$$
C_{f r}=\frac{\left(J_{i}-J_{c}\right)}{J_{i}}
$$


where $J_{i}, J_{c}$ - wear rate at intermittent and continuous friction.

The wear resistance of borated and especially chrome-plated steels is much higher than unhardened and hardened ones (table 3). The wear resistance of chrome-plated steels is approximately equal to that of $\mathrm{Cr} 18 \mathrm{~N} 9 \mathrm{~T}$ stainless steel $[4,7,11]$. Theless wear resistance of borated steels as compared to chrome-plated steels is explained by the fact that a grid of microcracks forms on their surface, in the borated layer, whichsplit during friction, and the corroding medium penetrates through them to the base metal.

Table 3.Various steelswear rate $(\mathrm{mg} / \mathrm{h})$ during mineral fertilizers friction

\begin{tabular}{|l|c|c|c|c|}
\hline \multicolumn{1}{|c|}{ Type } & $\begin{array}{c}\text { Phosphorite meal } \\
\text { with a damp } \\
\text { content 9\% }\end{array}$ & $\boldsymbol{C}_{\mathrm{fr}}$ & $\begin{array}{c}\text { Ammonium sulfate } \\
\text { with a damp } \\
\text { content 4\% }\end{array}$ & $\boldsymbol{C}_{\mathrm{fr}}$ \\
\hline Unhardenedsteel 45, & $21.2 / 22.9$ & 0.08 & $17.4 / 138.7$ & 6.96 \\
\hline Chromeplatedsteel 45 & $0.3 / 0.3$ & 0.00 & $0.2 / 0.2$ & 0.00 \\
\hline Borated steel 45 & $4.9 / 3.4$ & 0.10 & $2.3 / 40.3$ & 16.50 \\
\hline ChromeplatedST3 & $0.5 / 0.5$ & 0.00 & $0.3 / 0.3$ & 0.00 \\
\hline Borated steel ST3 & $3.2 / 3.5$ & 0.10 & $2.4 / 38.8$ & 15.18 \\
\hline ChromeplatedST5 & $0.4 / 0.4$ & 0.00 & $0.2 / 0.2$ & 0.00 \\
\hline Borated steel ST5 & $4.5 / 4.9$ & 0.09 & $1.9 / 26.0$ & 12.69 \\
\hline Hardened steel 45 & $15.2 / 17.1$ & 0.12 & $19.2 / 173.2$ & 8.02 \\
\hline UnhardenedsteelCr18N9T & $0.4 / 0.4$ & 0.00 & $0.3 / 0.3$ & 0.00 \\
\hline $\begin{array}{l}\text { Note. The numerator contains data for continuous friction, in the denominator for intermittent } \\
\text { one }\end{array}$
\end{tabular}

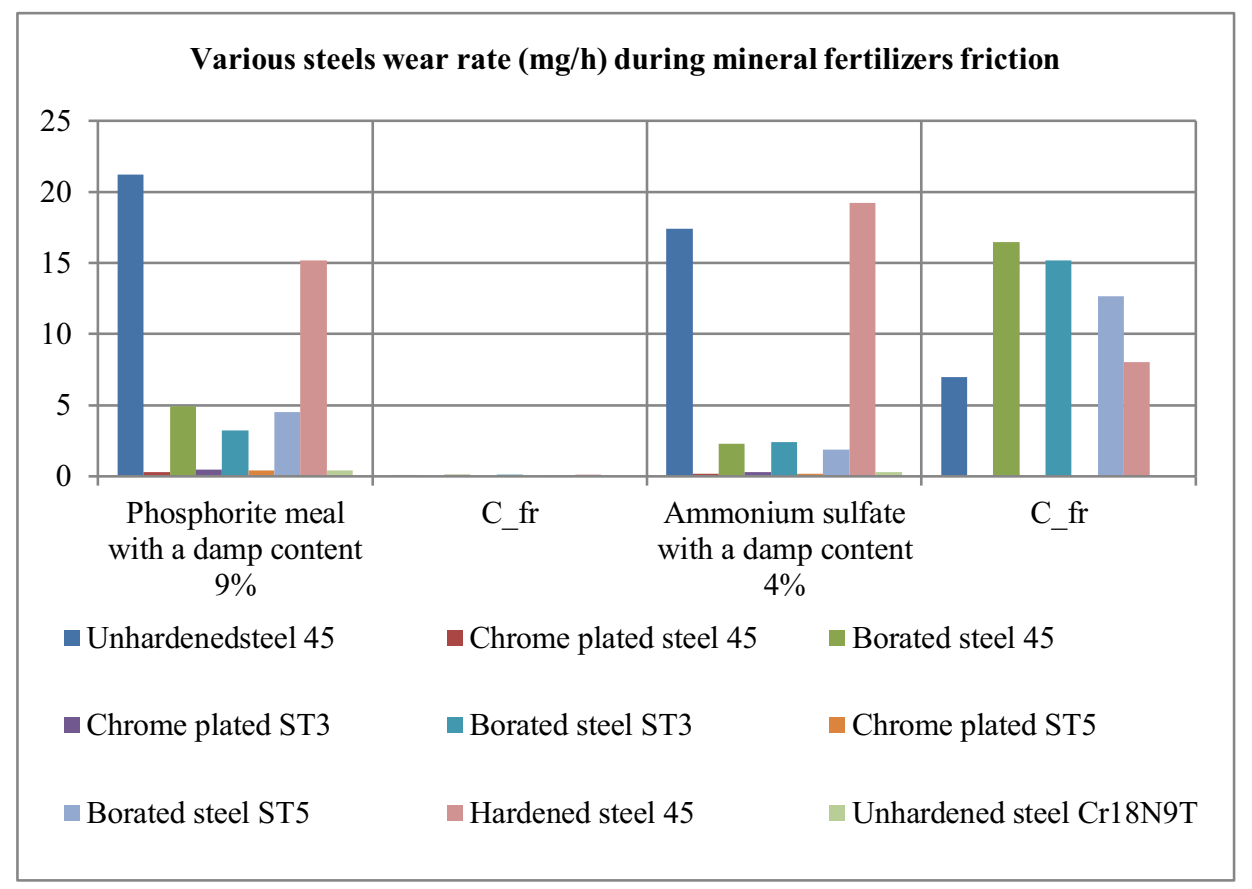

There has been no wear recorded in testing the dippers of the 1RMG-4 spreader working disks hardened by thermodiffusionchromizing after 500 hours of service.

Storage periodis animportant reserveor increasing the mechanical life of implements operating in corrosive environments.For liquid inhibited greases unlike stiff ones, the determining factor is not the permeability of the electrolyte through the coating film, but the 
adsorption-chemisorption properties, the presence of which is proved by the aftereffect, i.e. stainlessness after degreasing.Moreover, the protective effectiveness of liquid inhibited oilbased thin-film coatings is due to a semi-solid film that forms during the solvent evaporation by the action of adhesive cohesive forces $[6,12]$.

The protective ability of a bituminous coating increases after adding an inhibited lubricant into it. Anodic and cathodic polarization of samples coated with a mixture of bitumen and NG-204U occurs much faster than when they are coated only with bitumen. This is due to the good conditions for the formation of chemisorption protective films if an inhibited product is included. A mixture consisting of $85 \ldots 90 \%$ bituminous grout and $10 \ldots$ $15 \%$ inhibited grease is optimal.

\section{Conclusion}

Silica sand as a filler, has a great influence on the wear of rubberized coats based on polychloroprene NT. The minimum wear is at a content $(35 \ldots 40 \%)$. The performance tests of the 1RMG-4 spreader's rubberized parts have showed that their service life is $8 \ldots 10$ times longer than that of the batch ones. Surface alloying during thermochemical treatment gives the best results in increasing the wear resistance of structural steels. Chromium and boron have been chosen from a large number of different elementsfor the study that can form diffusion coatings. First, chrome-plated and borated surfaces have abrasion and rust resistant. Secondly, diffusion chromium plating and borating are relatively widespread. The hard thermal diffusion chromium plating and borating of St3, St5 and Steel 45have been used.The composition of the saturating mixture for chromium plating $(\%$ of the received mass): 40 - aluminum oxide, 52 - chromium oxide and 8 - aluminum powder. To activate the process of diffusion saturation, $2 \%$ of ammonium chloride (to the total mass) has been added. The duration of the process is $8 \mathrm{~h}$, temperature is $1050{ }^{\circ} \mathrm{C}$.

The composition of the saturating mixture for borating (\%): 80 - aluminum oxide, 14 boron oxide and 6 - aluminumpowder. To activate the process, $2 \%$ sodium fluoride has been added. Duration of the process is $6 \mathrm{~h}$, temperature is $920^{\circ} \mathrm{C}$. It is most expedient to use conserving materials on farms prepared on the basis of used engine and gear-box oils with the addition of special inhibitedmaterials. Equipment for liquid complex fertilizing is reliably protected against corrosion by sacrificial inhibitory protection.

\section{References}

1. $\quad$ S.G. Anuryev, I.A. Kiselev, Young scientist, 11.3 (145.3), 57-59 (2017)

2. N.P. Doronina, Y.I. Zhevora, M.L. Pantukh, Scientific review, 21, 75-78 (2016)

3. A.V. Gorkin, Transport infrastructure of the Siberian region, 1, 637-641 (2018)

4. J. Khara, M.V. Sheladiya, G.D. Acharya, IUP Journal of Mechanical Engineering, 12(2), 43-64 (2019)

5. I.N. Kravchenko, M.V. Dobychin, K.V. Makarov, N.I. Salyaev, Construction and road machines, 5, 25-32 (2016)

6. A.S. Kryshkina, N.S. Burtyleva, T.V. Pomazan T.V., 509-515 (2016)

7. V.N. Kuznetsova, Y.V. Yarmovich, Bulletin of the Belgorod State Technological University named after V.G. Shukhova, 9, 109-114 (2016)

8. A.N. Lutsenko, A.B. Laptev, The proceedings of the III All-Russian Scientific and Technical Conference, 179-200 (2018)

9. V.P. Lyalakin, I.G. Golubev, Machinery and equipment for a rural, 4, 41-43 (2016) 
10. N.N. Sergeev, M.V. Ushakov, A.N. Sergeev, and others, Bulletin of the Tula State University. Technical Sciences, 3, 591-601 (2019)

11. N.V. Titov, The proceedings of the VI International Youth Scientific Conference, 4 , 217-221 (2016)

12. N.V. Vodolazskaya, A.G. Minasyan, O.A. Sharaya, Innovations in the agroindustrial complex: challenges and opportunities,3 (11), 14-23 (2016)

13. M.A. Zagorodnikova, V.P. Yartsev, P.V. Monastyrev, Bulletin of the Tambov State Technical University, 22 (4), 657-665 (2016) doi: 10.17277/vestnik.2016.04.pp.657665.

14. V.L. Zakovorotny, V.P. Lapshin, T.S. Babenko, Russian Engineering Research, 38(9), 707-708 (2018) doi: 10.3103/S1068798X18090290

15. S.Y. Zhachkin, E.V. Pukhov, G.I. Trifonov, Y.V. Komarov, K.V. Zagoruiko, Bulletin of the Voronezh State Agrarian University, 12, 3 (62), 32-40 (2019) 